\title{
Treatment of Thyponium Flageliforme in Combination with Curcuma Zedoaria, and Phyllanthus Niruri Synergistically Enhances Apoptotic and Anti-Proliferative Effect on Breast Cancer
}

\author{
Chodidjah $^{1}$, Eni Widayati ${ }^{2 *}$ and Taufiqurrachman Nasihun ${ }^{3}$ \\ ${ }^{1}$ Department of Anatomy and Master Program of Biomedical Sciences of Sultan Agung Islamic University, \\ Semarang, Indonesia; eniwidayanti@unissula.ac.id \\ 2Department of Chemistry, Medical faculty of Sultan Agung Islamic University, Semarang, Indonesia \\ ${ }^{3}$ Department of Biochemistry, and Master Program of Biomedical Sciences of Sultan Agung Islamic University, \\ Semarang, Indonesia
}

\section{Abstract}

Introduction: Breast cancer is the most common cancer and the second leading cause of cancer death in women. Combinations of Thyponium flageliforme, Curcuma zedoaria and Phyllanthus niruri (TCP) have been proven as immunomodulator and retarded tumor progression in vivo. Objective: to investigate the apoptotic and anti-proliferative effect of TCP in C3H mice suffered from adenocarcinoma cells. Methods: 18 mice inoculated with one million cells of breast adenocarcinoma per mouse were assigned into three groups, TCP with dosage 85 and $125 \mathrm{mg}$ were treated for 21 days to evaluate tumor volume, expression of $\mathrm{Ki}-67$ and Capase3. Expression of $\mathrm{Ki}-67$ and Capase 3 were measured by immunohistochemistry staining, whilst cancer volume was assessed using calipers. Results: Mann Whitney analysis indicated that tumor volume in TCP groups were lower, otherwise for expression of caspase,$p<0.05$ respectively. Whereas expression of Ki-67 in TCP groups was lower, but not significant, $p>0.05$. Conclusion: TCP treatment with 85 and $125 \mathrm{mg}$ dosage capable of reducing tumor volume, increasing caspase ${ }_{3}$ and lowering Ki-67 expression.

Keywords: Apoptosis, Breast Cancer, Thyponium flageliforme, Tumor Volume

\section{Introduction}

Breast cancer is the most common malignant tumor and the second leading cause of cancer death in women worldwide ${ }^{1}$. The incidence of the mammary gland cancer highest is in North America and Northern Europe and lowest in Asia and Africa ${ }^{2,3}$. The incidence rate of breast cancer in Asia Pacific is about 43 per 100.000 populations. Of that China is the highest incidence (46\%), followed by Japan (14\%) and Indonesia $(12 \%)^{4}$. So far, the treatments of breast cancer consisting of surgery particularly in primary tumor, and radiotherapy,

\footnotetext{
${ }^{*}$ Author for correspondence

Email: eniwidayanti@unissula.ac.id
} 
as well as chemotherapy; unfortunately it was not effective, even left various side effects such as hair loss, nail changes, infertility, and premature menopause ${ }^{5}$. In Indonesia Thyponium flageliforme (TF), Curcuma zedoaria (CZ), and Phyllanthus niruri (PN), abbreviated as TCP are known as traditional plants that capable of enhancing the immune response or retarded the breast cancer cells progression in vivo ${ }^{6}$. However, the underline effect mechanism of TCP treatment on breast cancer in vivo remains inconclusive.

The previous studies demonstrated that administration of PN alone has been proven capable of increasing the expression caspase 3 and 7 and indeed apoptosis in cell line cancer ${ }^{7,8}$. Another evidence also indicated that treatment of PN extract was able to inhibits cell cancer metastasis mediated by tumor cell invasion and blocking migration in the culture of Human Lung (A549) and breast cancer cells (MCF, -7) in vitro respectively ${ }^{9}$. Treatment with $\mathrm{CZ}$ alone at the dose of $300 \mathrm{mg} / \mathrm{kg}$ and $750 \mathrm{mg} / \mathrm{kg}$ Body Weight (BW) has been proven able to inhibit expression of p53 and $\mathrm{H}$-ras in mutant mammary gland cells. Moreover, administration of $\mathrm{CZ}$ also able to reduces the incidence of mammary gland tumors in rats ${ }^{10}$. In addition, treatment of TF orally at the dose of 200,400 , and $800 \mathrm{mg} / \mathrm{kg} \mathrm{BW}$ in $\mathrm{BALB} / \mathrm{c}$ mice leukemia during 28 days was evidenced reduces the number of immature granulocyte cells in the peripheral blood circulation ${ }^{11}$ Furthermore, my previous study demonstrated that administration of TF syrup at the dose of 40 and $80 \mathrm{mg} / \mathrm{ml}$ once daily for 25 days in $\mathrm{C} 3 \mathrm{H}$ mice were inoculated with breast cancer cells, albeit capable of lowering expression of Her2neu protein, but did not reduce the tumor volume. The active substance that mediates $\mathrm{PN}, \mathrm{CZ}$, and TF action on tumor including expression of p53, caspase 3 and 7 , and reducing immature granulocyte in peripheral blood circulation is polyphenols, curcumin, and flavonoids respectively. Refer to the previous study aforementioned, administration of TCP alone on breast cancer both in vitro and in vivo did not effective. Therefore in the present study treatment with combination of TCP on breast cancer in vivo, will synergistically reduce tumor volume mediated by enhancing of tumor cells apoptosis and debilitate cells tumor proliferation.

In principal, the breast cancer progression is determined in one hand by uncontrollable cellular proliferation due to DNA mutation, such as BRCA1 and BRCA2 genes mutation. In normal condition these genes prevent cancer by encode protein synthesis to keep the cells from growing abnormally. By these mutation genes cannot block growth abnormally, and that lead to cancer formation ${ }^{5}$. On the other hand, despite the cellular proliferation is normal, however, its progression continuously persisting caused by impairment of gen suppressor tumor such as p53. Protein p53 produced by P53 gene is a genome guard, by which abnormal cell growth can be controlled. Inherited mutation of this gene cause Li-Fraumeni Syndrome and people with this syndrome have an increased risk of breast cancer ${ }^{5}$. In addition, gene mutations will induce expression of p53 and lead cells into G1 arrest for repairing or apoptosis dependent on the scale of mutation. In certain extent mutation and double strand gen damages can be repaired by the available mechanism in the body hence prevent cancerogenesis. However, in large extent genes damage may induce unrepaired genes and mutation and result in cancer due to uncontrollable proliferation and impairment of apoptosis. Therefore, concern of pharmacological treatment in cancer to date is addressed to induce the cells cancer apoptosis and suppress cells proliferation. The growing evidences indicated that flavonoids is one of the most popular plant (including TCP) constituent and commonly used by human worldwide. Flavonoids, however have various pharmacological properties ${ }^{12,13}$, including antiinflammatory, antioxidant, and cytotoxic anti-tumour activities $^{12,14}$. Objective of the present study to proof the treatment of TCP combination is synergistically able to reduce tumor volume mediated by increase in apoptosis and debilitate cells tumor proliferation. Increase in apoptosis characterized by elevation of caspase 3 expression, and debilitated cells proliferation marked by decrease in expression of Ki-67.

\section{Methods}

In experimental study with Post test only control group design, a total of 18 female mice $\mathrm{C} 3 \mathrm{H}$ (3 month old and 50 gram body weight) were used, obtained from the laboratory of animal of Indonesian University medical college. All mice have been inoculated with breast cancer cells taken from a donor mouse and assigned into 
3 groups, six mice of each. (1) Control Group (C-G), mice were treated with distilled water. (2) $85 \mathrm{mg}$ TCP group (TCP-85), mice got $85 \mathrm{mg} / \mathrm{BW}$ TCP. (3) $125 \mathrm{mg}$ TCP group (TCP-125), all mice were treated with TCP $125 \mathrm{mg} / \mathrm{BW}$. All treatments were given orally in 0.2 $\mathrm{ml}$ solution once daily for 21 days. All mice were kept in acclimatization for one week with environmental controlled temperature $\left(20-24{ }^{\circ} \mathrm{C}\right)$, constant humidity (55-60\%), and controlled photoperiod (12 h light and 12 $\mathrm{h}$ dark) properties, with food and water ad libitum before start of the experiment. At the end of the study (day 22), the size of the tumors was measured manually (length, width, height in $\mathrm{mm}$ ) using calipers. Furthermore, all rats were anesthetized with an intramuscular injection of $50 \mathrm{mg} / \mathrm{kg}$ ketamine hydrochloride (Ketalar) and a tissue cancer sample was taken to form histopathology slides preparation to determine $\mathrm{Ki}-67$ and caspase 3 expression. All slides preparations were stained with immunohistochemistry method. All animal protocols were approved by the Research Ethics Committee of Sultan Agung Islamic University Medical Faculty, Semarang, Central Java, Indonesia.

\subsection{TCP Extract}

TCP was obtain from the market and extracted by Soxhlet methods from the whole plants. The extracts were prepared in the laboratory of Sultan Agung Islamic University Medical Faculty, Semarang, Central Java Indonesia

\subsection{Breast Adenocarcinoma Cells Inoculation}

Following mice were acclimated, one million cells of breast cancer was inoculated by subcutaneous injection of $0.2 \mathrm{ml}$ tumor pulp into fat pad of mice. The tumor pulp was prepared from a tumor (breast cancer) taken from a donor mouse that had been sacrificed by ether anesthesia. The tumor was powdered, then physiologic saline was added in a 1:1 ratio.

\subsection{Histopathology Slides Preparation}

The histopathology slides were prepared by deparaffining, i.e., immersion of the tissue sections in xylol for 2 minutes, then in absolute ethanol, 95\% ethanol, 80\% ethanol, and $70 \%$ ethanol, respectively, for 1 minute, and then running water for 10-15 minutes. After immersed in $3 \% \mathrm{H}_{2} \mathrm{O}_{2}$ during 30 minutes, the slides washed three times in PBS for 2 minutes each, placed in $0.25 \%$ trypsin for 6 minutes at $37^{\circ} \mathrm{C}$, and then washed again in PBS three times for 2 minutes each. After that, the slides were immersed in the solutions of monoclonal antibody anticaspase 3 and anti Ki67 for 30 minutes. Subsequently the slides washed three times in PBS for 2 minutes of each, then placed in peroxidase-labeled secondary antibody solution, washed three times in PBS for 2 minutes each, placed in chromogen substrate solution for 5 minutes, washed three times in PBS for 2 minutes each, then washed in distilled water. Lastly the slides were immersed in Mayer Hematoxylin stain for 6 minutes, washed in running water, and dehydrated, cleared, and mounted. The reagents used for preparation of the histopathology slides comprised: $\mathrm{H}_{2} \mathrm{O}_{2} 3 \%$; trypsin $0.25 \%$ in Phosphate Buffered Saline (PBS); 3,3'-Diaminobenzidine (DAB) solution (as color indicator) prepared from $1 \mathrm{ml}$ distilled water, 50 drops of $\mathrm{H}_{2} \mathrm{O}_{2}$ buffered substrate, one drop of DAB stock solution; xylol, absolute ethanol, and ethanol at concentrations of $70 \%, 80 \%$, and $95 \%$; anti caspase3; and anti-Ki67.

\subsection{Assessment of Ki-67 and Caspase3 Expression}

Ki67 and caspase 3 expression as indicator of cellular proliferation and apoptosis respectively, were determined by Alred Score methods. The number of Ki-67 and caspase 3 expressions was identified by light microscopy at $400 \mathrm{x}$ magnifications in 10 fields of view of each slide. Two hundred cells in each field were counted and determined the number of Ki-67 and caspase 3 expression. The expression of Ki-67 characterized by the brown colored simply in nucleus, whereas caspase 3 marked by the brown colored in both cytoplasm and nucleus.

\subsection{Statistical Analysis}

The total number of Ki-67 and caspase 3 expression were calculated and presented as the mean \pm SEM. Differences between groups were analyzed for statistical significance, using a Kruskal Wallis and Man Withney (SPSS 22.0). A level of $\mathrm{p}<0.05$ was considered as statistically significant. 
Treatment of Thyponium Flageliforme in Combination with Curcuma Zedoaria, and Phyllanthus Niruri Synergistically Enhances Apoptotic and Anti-Proliferative Effect on Breast Cancer

\section{Results}

In all mice, a palpable tumor have grown and seen at the size of about $2 \mathrm{~mm} \times 2 \mathrm{~mm} \times 1 \mathrm{~mm}$ following one week adenocarcinoma inoculation. Therefore further treatment of TCP on mice suffer from cancer can be performed. Following treatment of TCP for 21 days on those mice, the assesment result of tumor volume, expression of Ki-67 and caspase 3 can be seen in table 1 .

Table 1: Tumor volume, expression of Ki-67 and Caspase 3 after treatment of TCP

\begin{tabular}{|c|c|c|c|c|}
\hline \multirow[t]{2}{*}{ Variables } & \multicolumn{3}{|l|}{ Groups } & \multirow{2}{*}{$\begin{array}{l}\text { P } \\
\text { Kruskal } \\
\text { Wallis }\end{array}$} \\
\hline & $\begin{array}{l}\text { C-G } \\
(n=6)\end{array}$ & $\begin{array}{l}\text { TCP-85 } \\
(n=6)\end{array}$ & $\begin{array}{l}\text { TCP-125 } \\
(n=6)\end{array}$ & \\
\hline Tumor vol. Before treatment $\left(\mathrm{mm}^{3}\right)$ & 41.00 & 47.07 & 33.64 & - \\
\hline Tumor vol. after treatment $\left(\mathrm{mm}^{3}\right)$ & 2772.58 & 50.99 & 336.14 & - \\
\hline $\begin{array}{l}\Delta \text { between before and after } \\
\text { treatment }\left(\mathrm{mm}^{3}\right)\end{array}$ & $\begin{array}{l}2306.98 \\
(+1151.30)\end{array}$ & $\begin{array}{l}3.92 \\
(+38.26)\end{array}$ & $\begin{array}{l}302.50 \\
(+266.64)\end{array}$ & $<0.05$ \\
\hline Ki-67 Expression (\%) & $\overline{3.8}(+0.37)$ & $\overline{2.8}(+0.80)$ & $\overline{3.6}(+0.67)$ & $>0.05$ \\
\hline Caspase3 Expression (\%) & $6.2(\overline{+0} .2)$ & $8.4(\overline{+} 0.40)$ & $10.2 \overline{(+} 0.48)$ & $<0.05$ \\
\hline
\end{tabular}

\subsection{Tumor Volume after Inoculation of Adenocarcinoma Cells}

The result of the study as shown in table 1 indicate that after inoculation of adenocarcinoma cells on mice, the highest $\Delta$ between tumor volume before and after treatment was in C-G, followed by TCP-125, and the lowest was in TCP85. Kurskal Wallis analysis on tumor volume displayed that there was significant difference amongst groups, $\mathrm{p}<$ 0.05 . Mann Whitney analysis showed that tumor volume in C-G was significant higher compared to that of TCP-85 and TCP-125, $\mathrm{p}<0.05$. In contrary, tumor volume in TCP-85 was significant lower compared to that of TCP$185, \mathrm{p}<0.05$ (Figure 1).

\subsection{Expression of $\mathrm{Ki}-67$}

Expression of Ki-67 was highest in C-G, followed by TCP125 , and the lowest was in TCP-85. However, Kruskal Wallis analysis on expression of Ki-67 amongst groups showed no significant difference, $\mathrm{p}>0.05$ (Figure 2).

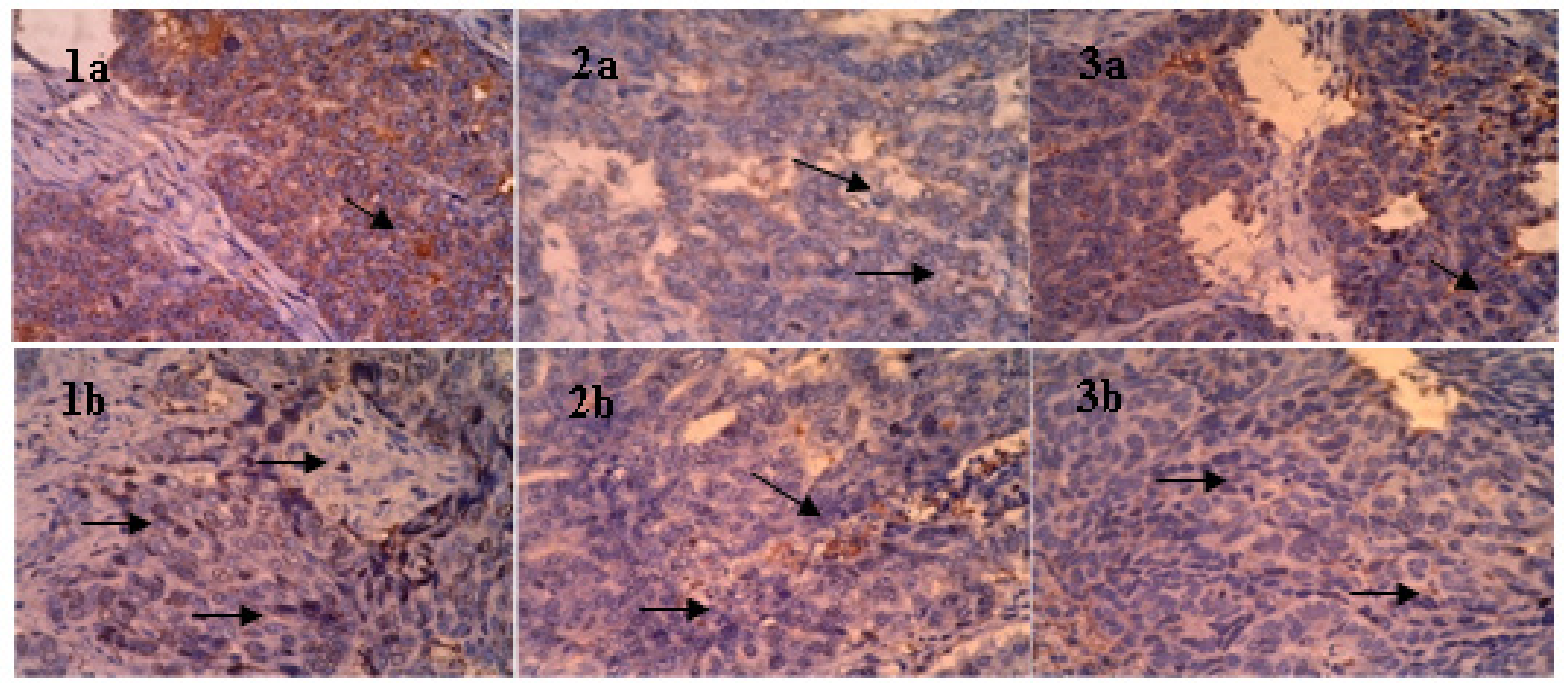

Fig. 1. Expression of caspase3 in C-G (1a); expression of caspase3 in TCP85 (2a); expression of caspase3 in TCP 125 (3a). Expression of Ki-67 in C-G (1b); expression of Ki-67 in TCP 85 (2b); expression of Ki-67 in TCP 125 (3b). 

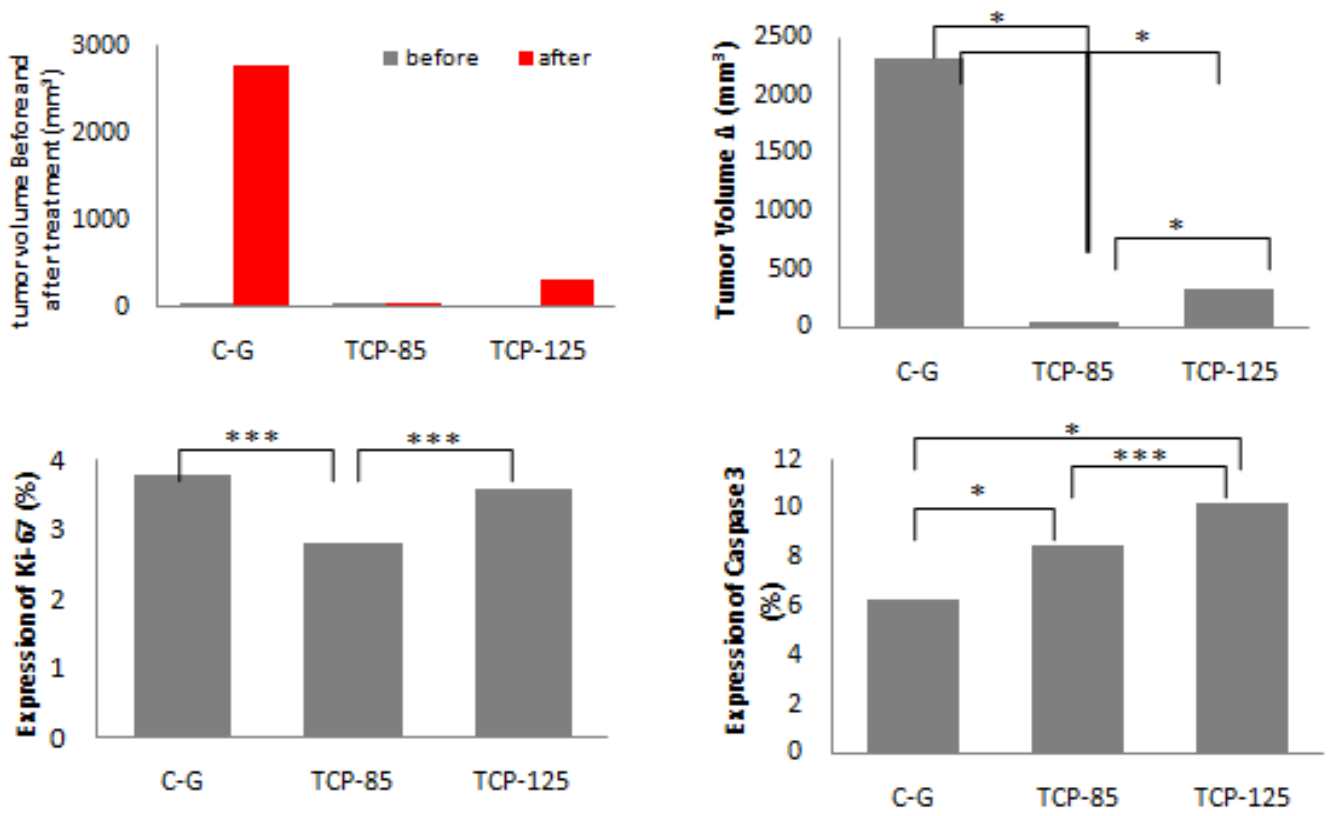

Fig. 2. Tumor volume before and after treatment, The $\Delta$ (differences) of Tumor Volume, Expression of Ki-67 and Caspase3 amongst groups. Mann Withney Analysis: ${ }^{*} \mathrm{p}<0.05 ;{ }^{* *} \mathrm{p} 0.05$; *** $p>0.05$.

\subsection{Expression of Caspase3}

Expression of caspase 3 was highest in TCP-125, followed by TCP-85, and the lowest was in C-G groups. Kruskal Wallis analysis on caspase 3 amongst groups showed significant difference, $\mathrm{p}<0.05$. Moreover, Mann Whitney analysis demonstrated that the expression of caspase 3 in TCP-85 and TCP-125 were higher compared to that of $\mathrm{C}-\mathrm{G}, \mathrm{p}<0.05$. Otherwise, expression of caspase 3 in TCP125 compared to that of TCP-85, were not difference significantly, $\mathrm{p}>0.05$ (Figure 2 ).

\section{Discussion}

In the present study to develop breast cancer was used breastadenocarcinomacellsinoculation onfatpad of mice. The result indicated that inoculation of adenocarcinoma cell was proved capable of growing carcinoma in a week. This result in line with the study was reported by Sousa and coworkers that orthotropic inoculation of breast carcinoma cell on normal mice capable of inducing growth, development, and even metastasis. After tumor inoculation within 7 days, involvement of positive lymph node with micro metastases was observed in $85 \%$ of the animals in ipsilateral sentinel lymph node (SLN; right sub iliac node) and contra lateral lymph node (LN; left sub iliac node). However, in the group of 14 days, there were metastatic deposits in the ipsilateral SLN and contra lateral $\mathrm{LN}$ in $100 \%$ and $50 \%$ of animals, respectively ${ }^{15}$. The Study of Gregoreo and coworkers also demonstrated that inoculation of breast cancer cells $4 \mathrm{~T} 1$ was able to induce primary tumor growth and metastasis in mice ${ }^{16}$. Another study reported by Neudert at al. also pointed out that inoculation of breast cancer into femoral artery was able to stimulate multiple osteolytic lesions in the distal femoral and proximal tibiae within 18 days after inoculation, with a success rate of $95-100 \%$ and no additional co morbidity ${ }^{17}$. Lastly, inoculation of tumor cells isolated from human suffer from breast cancer into mammary fat pad of nude mice was significantly induce breast cancer develop and metastasis to multiple mouse organs ${ }^{18}$ Nevertheless, in the present study the tumor volume resulted from breast cancer inoculation in all groups were not similar (comparable) in size. The highest volume occurred in TCP-85, followed by C-G, and the lowest was in TCP-125 (Figure 2). Accordingly, to evade the information bias in all groups, tumor volume were measured following treatment with TCP is the $\Delta$ (difference) tumor volume between before and after treatment. After treatment of TCP the highest $\Delta$ of tumor volume was in C-G, followed by TCP-125, and the 
lowest in TCP-85, suggesting that the most effective dose of TCP was TCP 85 and TCP 125 later on.

In addition to reduction of tumor volume, TCP treatment was also proven increase expression of caspase3, particularly in TCP-125 and TCP-85. Considering caspase3 is an executor enzyme in apoptosis mechanism, therefore increase in expression of caspase 3 suggesting that the rate of cellular apoptosis of tumor volume was also increased. Based on this result the tumor volume reduction in TCP-125 should be lower compared to that of TCP-85. Instead, in this study the tumor volume reduction in TCP-85 was higher compared to that of TCP-125. Eventhough, the tumor volume reduction in TCP-85 and TCP-125 was no significant difference, however this result is remain inconsistence, since the major constituent of TCP is flavonoids. There are various evidences that the proapoptosis effect of flavonoids on tumor cell was in the dose-effect dependent manner ${ }^{19,20}$. Moreover, in the view point of molecular biology this incosistence result possibly associated with DNA unfragmentation and chromatin uncondensation of tumor cells. It is possible since in some extent action of caspase 3 to dismantle cells and induce formation of apoptotic bodies needs prior chromatin condensation and DNA fragmentation ${ }^{21}$. Therefore, to induce chromatin condensation and DNA fragmentation, the dose of TCP may be increased twice or trice fold, considering poliphenol and flavonoids capable of inducing apoptosis on tumor cells were in supraphysiologis dose, however further study is needed. On the other hand, expression of Ki-67 as a marker of cellular proliferation during mitosis, were lowest in TCP85 followed by TCP-125, and C-G later on. Eventhough, the expression of Ki-67 in TCP-85, TCP-125, and CG was no significant difference, however this result was consistent with tumor volume reduction in TCP-85, TCP-125, and C-G. Taken together, this result imply that the tumor volume reduction was prominently associated with apoptosis and supression of proliferation induced by the high expression of caspase 3 and lower expression of Ki-67 (Figure 2).

The tumor volume reduction after treatment of TCP is attributable to the constituent of TCP consisting of terpenoids, phenylpropanoids, flavonoids, sesquiterpenes, curserenon, arismol, and curcumin. There are various evidences indicated that administration of these compounds (terpenoids, phenylpropanoids, flavonoids, and sesquiterpenes) were able to debilitate tumor progression and so called as anti-tumor ${ }^{6}$. Study was reported by Rachman and coworker showed that treatment with curserenon and arismol were extracted from CZ by hexan solvent capable of increasing expression of caspase 3 and apoptosis ${ }^{22}$. Moreover, in vitro study reported by Shin, et al. displayed that administration of curcumin in ovarian cancer cells line (Siha cells) was able to activate cytochrome $\mathrm{c}$ and caspase 3 and reduce up to $73 \%$ of ovarian cancer cell viability ${ }^{23}$. Mankaran and coworker also reported that administration of $\mathrm{TP}$ in cell cultures of human lung carcinoma (NCL-H23) was able to increase apoptosis detected by TUNNEL method $^{24}$. Study was reported by Fuida showed that CZ oil has cytotoxic effects on NSCLC cell cultures characterized by apoptosis ${ }^{25}$. In addition, CZ have also been proven increases the activity of caspase9, 8, and 3, and poly (ADPribose) polymerase (PARP). Otherwise, $\mathrm{CZ}$ decreased $\mathrm{Bcl}-2$ and $\mathrm{Bcl}-\mathrm{xl}$ protein in one side and increase $\mathrm{Bax}$ in another side, leading to increase Bax to $\mathrm{Bcl} 2$ ratio. Moreover, $\mathrm{CZ}$ also inhibit secretions of AIF and cytochrome c, Endo G to the cytoplasm as well as increase the expression P53 protein in H1229 cell culture $^{25}$. CZ also inhibit proliferation of H1229 cells line through the AKT and NF-kb (Chen, 2013).

\section{Conclusion}

Based on the result of the present study and aforemention discussion conclusion can be inferred that TCP treatment with 85 and $125 \mathrm{mg}$ dosage capable of reducing breast tumor volume, increasing caspase $_{3}$ and lowering Ki-67 expression.

\section{Acknowledgement}

The authors would like to thank the Directorate of Higher Education for funding this study. The authors also would like to acknowledge Puspita Ekawuyung, Susilorini, Slamet, and Agustin for their valuable contribution.

\section{Conflict of Interest}

The authors report no conflicts of interest. The authors alone are responsible for the content and writing of the paper. 


\section{References}

1. Jnr FNG, Anyanful A, Eliason S, Adamu SM, Debrah S. Pattern of breast cancer distribution in ghana: a survey to enhance early detection, diagnosis, and treatment. International Journal of Breast Cancer. 2016; 1-9.

2. Youlden DR, Cramb SM, Dunn NA, Muller JM, Pyke CM, Baade PD. The descriptive epidemiology of female breast cancer: An international comparison of screening, incidence, survival and mortality. Cancer Epidemiol. 2012; 36:237-48. PMid:22459198. https://doi.org/10.1016/j. canep.2012.02.007

3. Bombonati A, Sgroi DC. The molecular pathology of breast cancer progression. J Pathol. 2011; 223: 307-17. PMid:21125683 PMCid:PMC3069504. https://doi. org/10.1002/path.2808

4. Youlden DR, Cramb SM, Yip CH, Baade PD. Incidence and mortality of female breast cancer in the Asia-Pacific region. Cancer Biol Med. 2014; 11:101-15. PMid:25009752 PMCid:PMC4069805

5. American Cancer Society. Cancer Facts and Figures 2016. Atlanta, GA: American Cancer Society; 2016.

6. Lakshmi L, Padmaja G, and Remani P. Antitumor effects of isocurcumenol isolated from curcuma zedoaria rhizomes on human and murine cancer cells. International Journal of Medicinal Chemistry. 2011; 1-13. PMid:27429805 PMCid:PMC4939266. https://doi. org/10.1155/2011/253962

7. Tang YQ, Lee SH, Sekaran SD. Phyllanthus Sp a local plant with multiple medicinal properties. JUMMEC. 2014; $17: 1-8$.

8. Tang Y-Q, Jaganath IB, Sekaran SD. Phyllanthus spp. induces selective growth inhibition of PC-3 and MeWo human cancer cells through modulation of cell cycle and induction of Apoptosis. PLoS ONE. 2010; 5:e12644. PMid:20838625 PMCid:PMC2935893. https://doi.org/10.1371/journal. pone. 0012644

9. Lee SH, Jaganath, Wang SM, Sekaran S D. Antimetastatic effect of phyllanthus in human lung (A 549) and breast (MCF-7) cancer cell lines. Journal PLos one. 2011; e20994. PMid:21698198 PMCid:PMC3116853. https://doi. org/10.1371/journal.pone.0020994

10. Meiyanto E, Hamid IS. Modulasi cypla1 dan gst serta ekspresi p53 dan ras setelah induksi 7,12-dimethyl benz( $\dot{\alpha})$ antrasen (dmba) dan pemberian anti karsinogenesis gynura procumbens dan curcuma zedoaria pada tikus galur sprague dawley. J. Penelit Med Eksakta. 2009; 8:16877.
11. Mohan S, Abdul AB, Abdalwahab SI, Al-Zubairi AS, Sukari MA, Abdullah R, et al. Typhonium flagelliforme inhibits the proliferation of murine leukemia WEHI-3 cells invitro and induces apoptosis invivo. Leuk Res. 2010; 34:1483-92. PMid:20569984. https://doi.org/10.1016/j. leukres.2010.04.023

12. Kumar S, Pandey AK. Chemistry and biological activities of flavonoids: An overview. The Scientific World Journal. 2013; 1-16. PMid:24327805 PMCid:PMC3845396. https:// doi.org/10.1155/2013/962185

13. Mahomoodally MF, Gurib-Fakim A, Subratty AH. Antimicrobial activities and phytochemical profiles of endemic medicinal plants of Mauritius. Pharmaceutical Biology. 2005; 43:237-42. https://doi. org/10.1080/13880200590928825

14. Yamamoto Y, Gaynor RB. Therapeutic potential of inhibition of the NF- $\mathrm{KB}$ pathway in the treatment of inflammation and cancer. The Journal of Clinical Investigation. 2001; 107:135-42. PMid:11160126 PMCid:PMC199180. https:// doi.org/10.1172/JCI11914

15. Sousa CR, Miranda-Vilela AL, de Almeida MC, Fernandes JMS1, Sebben A, Magalhaes KG, et al. Breast cancer model developed through orthotopic Ehrlich cell injection for investigation of mechanisms in malignancy and metastasis; 2015.

16. Gregorio AC, Fonseca NA, Moura V, Lacerda M, Figueiredo $\mathrm{P}$, Simoes $\mathrm{S}$, et al. Inoculated cell density as a determinant factor of the growth dynamics and metastatic efficiency of a breast cancer murine model, PLoS ONE. 2016; e0165817 11:1-19.

17. Neudert M, Fischer C, Krempien B, Bauss F, Seibel Mj. Sitespecific human breast cancer (Mda-Mb-231) metastases in nude rats: model characterisation and in vivo effects of ibandronate on tumour growth. Int J Cancer. 2003; 107:468-77. PMid:14506749. https://doi.org/10.1002/ ijc.11397

18. Marsden CG, Mary Jo Wright MJ, Carrier L, Moroz $\mathrm{K}$, Pochampally R, Rowan BG. A novel in vivo model for the study of human breast cancer metastasis using primary breast tumor-initiating cells from patient biopsies. BMC Cancer. 2012; 12:1-16. PMid:22233382 PMCid:PMC3277457. https://doi.org/10.1186/14712407-12-10

19. Resende FA, Vilegas W, dos Santos LC, Varanda EA. Mutagenicity of flavonoids assayed by bacterial reverse mutation (ames) test. Molecules. 2012; 17:5255-68. PMid:22565478. https://doi.org/10.3390/ molecules 17032335 
Treatment of Thyponium Flageliforme in Combination with Curcuma Zedoaria, and Phyllanthus Niruri Synergistically Enhances Apoptotic and Anti-Proliferative Effect on Breast Cancer

20. Nasihun T, Widayati E. Administration of purwoceng (Pimpinellaalpina Molk) improves oxidative stress biomarker following UVC irradiationin Spargue-Dawley male rats. Journal of Natural Remedies. 2016; 15:82-91.

21. Porter AG, Janicke RU. Emerging roles of caspase-3 in apoptosis. Cell Death and Differentiation. 1999; 6:99-104. PMid:10200555. https://doi.org/10.1038/sj.cdd.4400476

22. Rahman ASM, Wahab AN, Malek ASN. In vitro morphological assessment of apoptosis induced by antiproliferative constituents from the rhizomes of Curcuma zedoaria. 2013.

23. Shin Y, Lee Y. Cytotoxic activity from curcuma zedoaria though mitochondrial activation on ovarian cancer cells. Toxicol Res. 2013; 29:257-61. PMid:24578796 PMCid:PMC3936178. https://doi.org/10.5487/ TR.2013.29.4.257
24. Mankaran S, Dinesh K, Deepak S, Gurmeet. Typhonium flagelliforme: A multipurpose plant. Int Res J Pharm. 2013; 4:45-8. https://doi.org/10.7897/2230-8407.04308

25. Fuida S, Debatin KM. Extrinsic versus intrinsic apoptosis pathways in anticancer chemotherapy. Oncogene. 2006; 25:4798-811. PMid:16892092. https://doi.org/10.1038/ sj.onc. 1209608

26. Chen CC, Chen Y, His YT, Chang CS, Huang LF, Ho CT, et al. Chemical constituents and anticancer activity of Curcuma zedoaria Roscoe essential oil against non-small cell lung carcinoma cells in vitro and in vivo. J Agric Food. 2013; 61:11418-27. PMid:24199734. https://doi. org $/ 10.1021 / \mathrm{jf} 4026184$ 